\title{
Effect of accumulation of nanoparticles in soil health- a concern on future
}

\author{
Zoya Javed $^{1 *}$, Kavya Dashora ${ }^{2}$, Mansi Mishra ${ }^{1}$, Vinayak D Fasake ${ }^{1}$ and Ayushi Srivastva ${ }^{1}$ \\ ${ }^{1}$ Research Scholar, Center for Rural development and technology, IIT Delhi, India \\ ${ }^{2}$ Assistant Professor, Center for Rural development and technology, IIT Delhi, India
}

\begin{abstract}
Nanotechnology proved as a boon to this era and is widely applied in many areas of science and technology. Agriculture is the backbone of industrial raw material and it is very important to have technologies supporting high yield, better crop production and protection in a cost effective, ecofriendly and sustainable way. Globally, there is a lot of research being conducted in the field of application of nanoparticles in agriculture. In recent time nano-based materials like nanoparticles and nanoformulations, nano-based fertilizers, nano-pesticides and insecticides, nano fungicides and other plant disease control formulations are available in the market. Though this technology offers many advantages, yet there are some vices which is causing the concern among the researchers and practitioners. The unregulated exposure of the nanoparticles to the soil is expected to cause adverse effects on the soil microbiota and in some cases negatively impact the important adaphic factors like soil infertility and toxicity. The studies conducted so far have shown diverse responses of nanoparticles by soil fungi and soil bacteria. The enzymatic activities of the microbes have been reported to be affected when the stress is induced from different sources. In some studies, silver nanoparticles have been found to decrease FDA- hydrolysis in soil. More research still needs to be done on addressing the nanoparticle induced metal-stress by different microbes. This review provides the comprehensive account of side effects of the nanoparticles on soil fertility and their effect on the different properties of soil and plant growth along with the research gaps in the field of soil application of nanoparticles and way forward to introduce an ecofriendly application of nanoparticles.
\end{abstract}

\section{Introduction}

Nanotechnology is one of the versatile technologies which find a wide application in material and living world. Nanoparticles have a size of 10-9 which works as an efficient carrier of the targeted molecules to atomic and subatomic levels and facilitate in development of novel things with desirable characteristics. This manipulation of atoms and molecules for design and development of novel products may be either top down which means reducing the size of the smallest structures to the nanoscale e.g. photonics applications in nanoelectronics and nanoengineering or the bottom up which involves manipulating individual atoms and molecules into nanostructures and more closely resembles chemistry or biology (Figure 1).

A nanometer is a billionth of a meter. Overall nano refers to a size scale between 1 nanometer $(\mathrm{nm})$ and $100 \mathrm{~nm}$ in at least one dimension and involves developing or modifying materials or devices within that size. To address the challenge of making technology more sustainable, ecofriendly and of precised application, nanotechnology is emerging up as a technology of choice. The research and application of nanotechnology in other sectors is gaining steady momentum, the same in agriculture and tool processing is yet to get in the mainstream research [1]. With the application of nanoparticles enhancing the soil fertility and supporting organic cycles in the soil, the microbial activity is enhanced which helps in addressing the wastelands, infertile lands and toxic landscapes to support vegetation and farming. In the existing croplands, the nanoparticles mediated nanofertilizers support in increasing the fertility and crop growth. Overall, nanotechnology provides the efficiency of the agriculture for a higher population. Since the agriculture sector has a huge responsibility of producing food for the world, the advent of technology and particularly, nanotechnology is probably going to encourage and outline the following phase of advancement of crops, animal farming, pesticides and accuracy cultivating strategies (Figure 2) [2].

\section{Nanotechnology in agriculture}

Agriculture farming is the foundation of most developing economies; roughly $60 \%$ of the population relies upon horticulture for their work. Indian farming division represents $18 \%$ of India's total national output (GDP) and gives work to 50\% of the workforce of the nation. Nanotechnology impacts the horticulture efficiency with the assistance of the Nano-fertilizer, Nano-pesticides or Nano-herbicides which act as a smart delivery system to plants, likewise the different industries making definitions with Nanoparticles $(100-250 \mathrm{~nm})$ to improve their activities by expanding Nanoparticles solubility in water. The soil is a very important component of the land and it is the mixture of organic matter, minerals, gases, liquid and organism that support the life on the earth.

\section{Soil}

Soil well-being has been defined as the limit of soil to work as a living framework, with the environment and land use limits, to continue plant and living system efficiency, keep up or upgrade water and air quality, and advanced plant and living organism's well-being. Solid soils keep up a various network of soil creatures that assistance to control

${ }^{*}$ Correspondence to: Javed Z, Research Scholar, Center for Rural development and technology, IIT Delhi, India, E-mail: zoya.aaidu@gmail.com

Key words: Nanotechnology, sustainable, microbiota, nano-pesticides, insecticides Received: June 24, 2019; Accepted: August 27, 2019; Published: August 30, 2019 


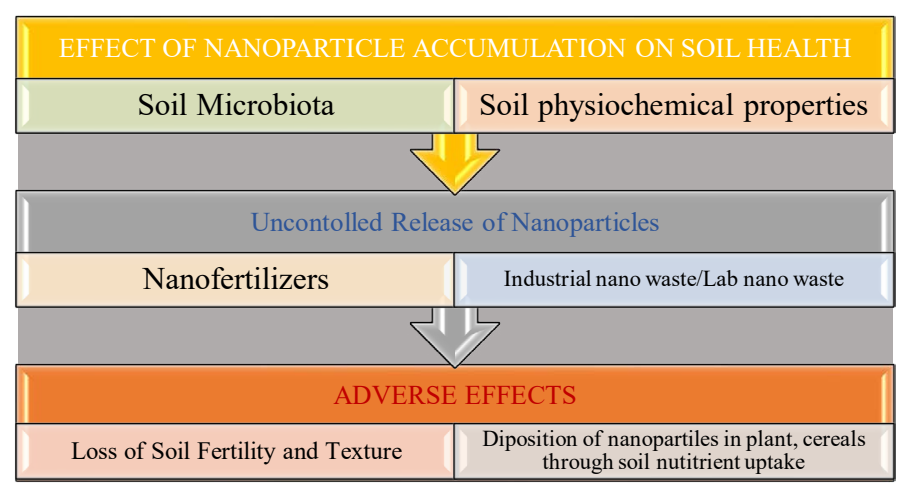

Figure 1. An Overview of Effect of nanoparticles on Soil Health

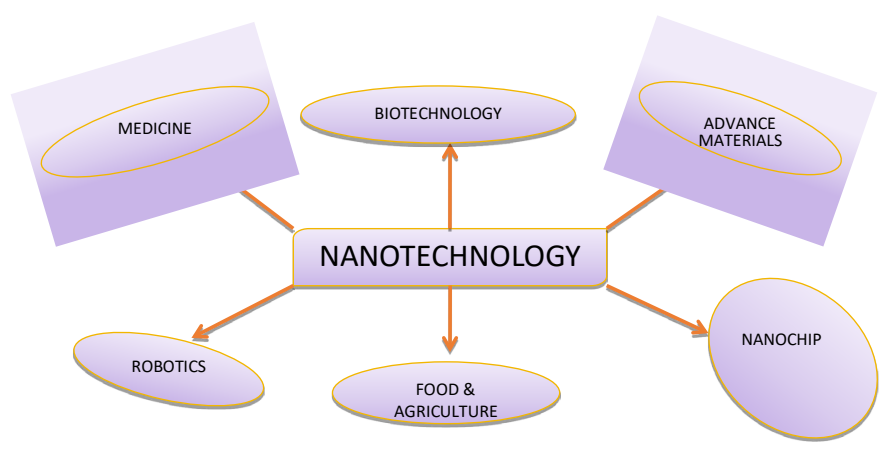

Figure 2. Nanotechnology and its relation with other fields

plant disease, pests, and insects, frame salutary cooperative relationship with plant roots; reuse fundamental plant supplements; enhance soil structure with positive repercussions for soil water and supplement holding limit, and improvement in the yield of crops [3]. There are four important factors i.e. carbon transformations, soil structure maintenance, control of pests and diseases and the nutrients cycle; play a significant role in the soil health. In detail, we can say that all these factors broadly depend upon biochemical process and microbial activities performed by a small microorganism present in the soil.

It is reported that NPs in medicine and biology was valued at US $\$ 17.5$ billion in 2011 with the further estimate to reach approximately US $\$ 53.5$ billion in 2017 and US $\$ 79.8$ billion in 2019 [4]. Silver NPs are estimated to be used up to $4 \mathrm{t}$ per year [5]. Zinc NPs are estimated to be produced up to $5500 \mathrm{t}$ per year replacing their bulk counterparts in a range of products [6].

The studies based upon the modeling and analysis provides a piece of information regarding synthesis, application and unsafe disposal of various nanoparticles in huge amount (several hundred tons) every year. Metallic oxide-based nanoparticles e.g. Ag, $\mathrm{Al}, \mathrm{C}, \mathrm{Ce}, \mathrm{Cu}, \mathrm{Fe}, \mathrm{Si}, \mathrm{Ti}$, $\mathrm{Zn}$ are accumulated in the environment in association with soil, sludge, and other wastes. Other natural resources like air and water are mostly contaminated with a significant amount of nanoparticles [7]. The increasing quantity of NPs is expected to prompt high concentration in the environment and potentially a higher risk to the living beings. Residues and deposits in large quantities will expand the likelihood of antagonistic associations between living things and nanoparticles [8]. It is reported that nanoparticles affect microscopic properties of soil, e.g., humic acid content and soil bacterial community [9] nanoparticles once released in the environment have an influence on microbial diversity and can also affect plant growth [10]. As the higher utilization of nanotechnology in numerous applications is increasing, it is raising various issues like ecological, toxicological, agricultural, well-being and security, mechanical, strategy, and administrative aspects. A few uses incorporate deliberate arrival of NPs into nature bringing about expanded quantity and concentration after a long time [11] without intense poisonous quality; bioaccumulation and long term exposure and presentation have unsurprising effects on the evolved way of life, which is unanswered [12].

\section{Types of nanoparticles}

Nanoparticles can be arranged into various forms as indicated by the size, morphology, physical and substance properties. Some of them are carbon-based nanoparticles, ceramic nanoparticle, metal nanoparticle, semiconductor based nanoparticle, polymeric nanoparticles and lipid-based nanoparticles. Based on shape, they can be classified into quantum dots, nanotubes, nanofibres, nanorods, nanosheets, aerogel and nanoballs [13] and can also be classified as either magnetic or nonmagnetic nanoparticles.

Metallic nanoparticles are silver $(\mathrm{Ag})$, gold $(\mathrm{Au})$, titanium oxide $\left(\mathrm{TiO}_{2}\right)$, iron oxide $\left(\mathrm{Fe}_{2} \mathrm{O}_{3}\right)$, zinc oxide $(\mathrm{ZnO})$, or copper $(\mathrm{Cu})$. Silver nanoparticles are the most utilized nanoparticles as antimicrobial operators for water treatment and in material enterprises; in gadgets, tranquilize drug transport, and agribusiness [14] Gold nanoparticles are used in the diagnosis of cancer, $\mathrm{TiO}_{2}$ used as photocatalyst due to no toxicity (Figure 3) (Table 1).

\section{Silver nanoparticles}

Silver nanoparticles are in size from 1 to $100 \mathrm{~nm}$. Usually illustrated as silver, but with a high surface dimension and a modest number of molecules contain an expansive measure of oxides. Different kinds of nanoparticles can be made depending upon the application. Silver nanoparticles (AgNPs) have novel physiochemical properties which enables them to be utilized in various field including medicine, food and mechanical industries application.

Silver nanoparticles have a high surface area and part of surface molecules; subsequently, have a high antimicrobial impact when contrasted with the bulk silver [15]. Antimicrobial property of silver nanoparticles has been utilized against a wide range of human pathogens [16-18]. In many cases, the maximum capacity is still to be investigated for product assurance. In this way, there is a developing enthusiasm to use the antimicrobial property of silver nanoparticles for plant disease management [19]. Silver nanoparticles have been testing as pesticides to diminish the weight of vermin from yields. Silver nanoparticles can be combined from physical, concoction and organic strategies. Attributable to the prerequisite of outrageous conditions and dangerous synthetic substances in physical and chemical strategies,

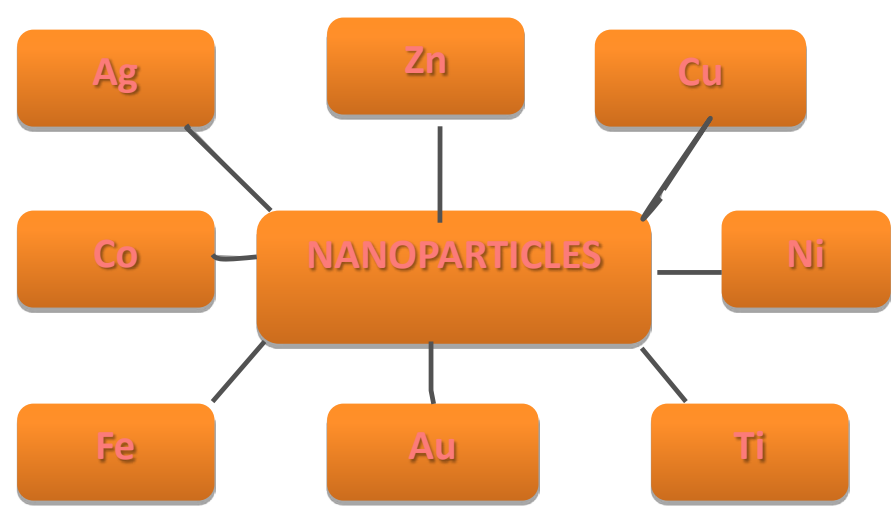

Figure 3. Different types of Nanoparticles 
Table 1. Types of nanoparticles and their uses

\begin{tabular}{|l|l|l|}
\hline \multirow{2}{*}{ CLASS } & TYPES & USES \\
\hline \multirow{2}{*}{ Metallic } & Silver $(\mathrm{Ag})$ & Drug delivery, Water Treatment, Electronic \\
\cline { 2 - 3 } & Gold $(\mathrm{Au})$ & $\begin{array}{l}\text { Cancer diagnosis, DNA fingerprinting, Stem } \\
\text { cell detection }\end{array}$ \\
\cline { 2 - 3 } & Titanium dioxide $\left(\mathrm{TiO}_{2}\right)$ & $\begin{array}{l}\text { Food additive, Water purification, medical } \\
\text { application }\end{array}$ \\
\cline { 2 - 3 } & Zincoxide $(\mathrm{ZnO})$ & Cosmetics, Drug delivery, biosensors. \\
\hline Copper $(\mathrm{Cu})$ & Electronics, catalyst, medicine, bioanalysis \\
\hline \multirow{2}{*}{$\begin{array}{l}\text { Carbon- } \\
\text { based }\end{array}$} & Fullerene & Drug carrier, medical imaging \\
\hline Silica-based & Siophene & $\begin{array}{l}\text { Cancer therapy, tissue engineering, bioimaging, } \\
\text { drug delivery. }\end{array}$ \\
\hline $\begin{array}{l}\text { Polymeric/ } \\
\text { Organic }\end{array}$ & $\begin{array}{l}\text { Chitosan poly (lactidoco- } \\
\text { glycolide), polyacrylate }\end{array}$ & Biosensor, Drug Additives \\
\hline
\end{tabular}

biomaterial-based techniques are broadly utilized in these days. Being single step union and eco-friendly, extraordinary analysts have organized silver nanoparticles from different sources (plants, bacteria, fungi etc.) These silver nanoparticles have been utilized to dispose of harmful microorganisms in plants. The introduction of the snails in the soil lattice to silver nanoparticles in a research facility was observed to diminish the movement and the feasibility of the land snail and about $20 \%$ of silver nanoparticles treated snail just as the recurrence of parasitic population in the encompassing soil [20]. Spherical shaped silver nanoparticles in size range of $\sim 10$ to $20 \mathrm{~nm}$ using culture supernatant of Serratia sp. BHU-S4 and their effective application for the management of spot blotch disease in wheat have experimented. Silver nanoparticles exhibited strong antifungal activity against Bipolarissorokiniana, the spot blotch pathogen of wheat. Effect of silver nanoparticles with diameters of $20 \mathrm{~nm}$ on seeds of Fenugreek (Trigonella foenum-graecum) has been carried out [21] different concentrations of silver nanoparticles were utilized and results demonstrated that extreme seed germination. These outcomes uncovered that utilization of silver nanoparticles could be utilized to significantly upgrade seed germination potential, means germination time, seed germination record, seed power file, seedling crisp weight, and dry weight.

\section{Zinc oxide nanoparticles}

Zinc deficiency is a most basic micronutrient issue that unfavorably influences farming generation in antacid soils with calcium carbonate [22]. The soil with calcium carbonate is a noteworthy wellspring of agribusiness in bone-dry or Mediterranean conditions of the world.

Zinc oxides $(\mathrm{ZnO})$ and zinc sulfates $\left(\mathrm{ZnSO}_{4} \cdot \mathrm{H}_{2} \mathrm{O}\right)$ or $\left(\mathrm{ZnSO}_{4} \cdot 7 \mathrm{H}_{2} \mathrm{O}\right)$ are generally utilized as zinc manures to address deficiency of zinc in soils [23]. The utilization of zinc oxide nanoparticles as zinc composts may build zinc disintegration and its bioavailability in soils with calcium carbonate. Zinc oxide nanoparticles antimicrobial action over vast zinc particles since the little size under $100 \mathrm{~nm}$ and high surfaceto-volume proportion of nanoparticles permits better connection with microscopic organisms [24].

Zinc oxide nanoparticles have the ability to induce reactive oxygen species (ROS) generation, which can lead to cell death when the antioxidative capacity of the cell is exceeded [25-28]. Zinc nanoparticles have shown to induce free radical formation in wheat, resulting in increased malondialdehyde and lower levels of reduced glutathione and reduced chlorophyll contents [29]. Zinc oxide nanoparticles utilizing leaf extract of Moringa oleifera in size range from 16 to $20 \mathrm{~nm}$ has been used as antimicrobial against bacterial strains, for example, Staphylococcus aureus, Bacillus subtilis, Pseudomonas aeruginosa, Proteus mirabilis, Escherichia coli, and other parasitic strains, for example, Candida albicans and Candida tropicalis utilizing the agar plate dissemination strategy has been tried. The most extreme zone of inhibition was seen in Staphylococcus aureus $(23.8 \pm 0.76)$ when contrasted with others. Circular and hexagonal zinc oxide nanoparticles from Parthenium hysterophorus L. have been blended by in costly, eco-friendly and basic strategy utilizing distinctive groupings of half and $25 \%$ of Parthenium leaf separates with size $27 \pm 5$ and $84 \pm 2 \mathrm{~nm}$, individually. These zinc oxide nanoparticles were investigated for the size-subordinate antifungal action against plant parasitic pathogens, for example, Aspergillus flavus and Aspergillus niger. A most extreme zone of inhibition was watched for $27 \pm 5 \mathrm{~nm}$ measure zinc oxide nanoparticles against Aspergillus flavus and Aspergillus niger. Parthenium synthesise zinc oxide nanoparticles turned out to be great antifungal specialists and condition neighborly [30]. Round formed zinc oxide nanoparticles with a normal size of 23 to $57 \mathrm{~nm}$ were set up by zinc acetic acid derivation and sodium hydroxide utilizing leaves of Catharanthus roseus (L.) G. Wear leaf separates. The orchestrated zinc oxide nanoparticles were assessed for antibacterial action against gram-negative microscopic organisms Escherichia coli (ATCC 25922) Pseudomonas aeruginosa (ATCC 15442), gram-positive Staphylococcus aureus (ATCC 6538) and Bacillus thuringiensis (ATCC 10792). Bacillus thuringiensis demonstrated the protection from zinc oxide nanoparticles pursued by Escherichia coli though Pseudomonas aeruginosa was more susceptible.

\section{Titanium dioxide $\left(\mathrm{TiO}_{2}\right)$ nanoparticles}

Titanium is a hard, corrosion safe metal and its compound titanium dioxide is a mainstream photo catalyst, utilized in the production of color pigments [31]. Titanium animates generation of more starches, empowering development and photosynthesis rate in plants [32]. Titanium dioxide has appeared reactant action for the debasement of pesticides [33]. Photo catalyst property of titanium dioxide has applications in plant assurance since it doesn't frame poisonous and unsafe substances thus have strong pathogen removal efficiency. Researchers are attempting to enhance the phytopathogenic sanitization productivity of titanium dioxide thin films by dye doping and other reasonable strategies [34]. Plants are likewise the most probable selection of researchers for the synthesis of titanium dioxide nanoparticles. Circular, grouped titanium dioxide nanoparticles with a normal size of $32.58 \mathrm{~nm}$ from the leaf concentrate of Psidium guajava have been integrated [35]. These nanoparticles were tried against microorganisms Aeromonas hydrophila (MTCC-1739), Proteus mirabilis (MTCC-442), Escherichia coli (MTCC1677), Staphylococcus aureus (MTCC-3160) and Pseudomonas aeruginosa (MTCC-4030). The highest zone of inhibition was seen against Staphylococcus aureus $(25 \mathrm{~mm})$ and Escherichia coli $(23 \mathrm{~mm})$ when titanium dioxide nanoparticles were utilized at $20 \mu \mathrm{g} / \mathrm{mL}$ fixation. The integrated $\mathrm{TiO}_{2}$ nanoparticles indicated upgraded antibacterial activity than the standard anti-microbial plate, antibiotic medication which decreased the odds for the advancement of anti-infection agents obstruction of bacterial species. The concentrate from plants and titanium dioxide nanoparticles orchestrated from these had the best cancer prevention agent activity when compared with ascorbic acid. Synthesis of spherical clusters, quite polydispersed titanium dioxide nanoparticles with a size range from 36 to $68 \mathrm{~nm}$ by Eclipta prostrata leaf extract has been done effectively [36].

\section{Application of nanotechnology in agriculture}

Agriculture practices like farming are the foundation of a large portion of the developing nations in which a huge income originates 
from agribusiness and the greater part of the population relies upon it for their job. The current worldwide population is almost 6 billion with half living in Asia. A huge extent of those livings in developing or emerging nations confront everyday nourishment deficiencies because of ecological effects or political shakiness, while in the created world there is a sustenance overflow. For emerging economies, the drive is to develop dry pest resistance and drought resistance crops additionally high yield. In emerged economies, the food business is driven by buyer request which is at present for fresher and more advantageous.

In farming and other agriculture practices, nanotechnology has been utilized for the controlled arrival of agrochemicals (e.g., composts, pesticides, and herbicides) and target-specific delivery of biomolecules (e.g., nucleotides, proteins, and activators) [37]. Nanotechnology has been utilized in the development fertilizers having a potential capacity of discharge and pesticides with better wide range bother insurance productivity [38]. Nanotechnology has been utilized to transfer DNA to plant cells, improve supplement ingestion, recognize plant pathogens, control plant hormones, and in animal farming, nanocapsules have been contrived to convey antibodies. Nanotechnology has a few applications in all phases of generation, preparing, putting away, bundling and transport of rural items [39]. Be that as it may, the vast majority of the work on nanotechnology in horticulture is at the developing stage and not yet popularize.

\section{Effect of nanoparticles on soil}

Soil is the largest receptor for the nanoparticles. Behavior of nanoparticles in the soil and their risk evaluation in arable soil ecosystems or other real environmental scenarios is very topical to date40. Soil is the natural matrix and rich in natural nanoparticles both as primary particles and as agglomerates/aggregates. Artificial entry of nanoparticle into the soil may have significant effect, as they may be extremely resistant to degradation and have the potential to accumulate in the soil.

Ben-Moshe, et al. (2013) reported affect of nanoparticles on many microscopic properties of the soil. The protection of soil microbial biomass and diversity is one of the major issues in the field of sustainable use of soils [41]. The effect of nanoparticle on the soil depends on their concentration, soil type, and enzymatic activity of soil. At high concentrations of nanoparticles, the negative effect on dehydrogenase enzymes activity was observed [42]. Another negative effect caused by nanoparticles is the influence on the rate of soil self-cleaning as well as on the balance of nutrients, which is the basis for the regulation of the processes of plant nutrition and soil fertility improvement $[43,44]$. It is significant to study presence of nanoparticle in soil and their influence on soil biodiversity [45].
Soil properties, such as $\mathrm{pH}$, texture, structure, and organic matter content, influence the soil microbial community and the ability of pollutants to have toxic effects on microorganism [46]. Nanoparticles could affect mobility of soil pollutants. Therefore, there is a need to compare the toxicity of the NPs in various types of soils. The soil amended with digestate and fly ash reduced the pollutant bioavailability. Another study suggests that particle size distribution and the composition of the organic matter change microbial populations in the contaminated soils [47]. Intentional influence on soil properties and composition and texture of the soil with various substances can also alter the effects of nanoparticles. Biochar is a soil minor change used for increasing soil fertility and productivity48show minimal effects of $\mathrm{CeO}_{2} \mathrm{NPs}$ on plants in biochar-amended soil. Interaction between NPs and biocharamended soil is not well studied.

\section{Effect of nanoparticles on crop growth}

The rapid growth of nanoparticle production and widespread use in agriculture have increased the quick development in the production of nanoparticle its application in farming and other agriculture practices have expanded the chances of coming and blending to the nanoparticles in the field' s soil (fertile soil of forms). It is presently notable that some nanoparticles influence crop improvement, plant advancement, yield, and huge numbers of them are aggregated in various plant tissues, including the eatable piece of plant tissues. It is difficult to survey the seriousness of the nanoparticles on the eco-frameworks and human wellbeing. It is trusted that nanoparticles are most troublesome sort of poison from manages and they are undetectable in view of its very small size (Nanometer range). Different investigations of the nanoparticles impact on yields, for example, onion, spinach, coriander, wheat, rice, soybean, mung bean, radish, lettuce, grain, cucumber, and tobacco have appeared of germination, diminished shoots and root development, poisonous quality, and diminishes in photosynthetic rate and chlorophyll contents'(Table 2) [49-57].

\section{Effect of nanoparticles on plant growth}

Nanoparticles related with plants causing different morphological and physiological changes, contingent upon the type and nature of the nanoparticles. The viability of nanoparticles is controlled by their substance synthesis, measure, surface covering, reactivity, and above all the portion at which they are successful [58]. Scientists from their investigations indicated both positive and negative impacts of nanoparticles on plant development and improvement, and the effect of designed nanoparticles (ENPs) on plants relies upon the structure, fixation, concentration, and biochemical and physical properties of NPs just as plant species (Table 3) [59-64].

Table 2. Effect of nanoparticles on the physiological changes in plants

\begin{tabular}{|c|c|c|c|}
\hline Types of Nanoparticle & Concentration & Physiological changes & References \\
\hline $\mathrm{TiO}_{2}$ & $10-2000 \mathrm{mg} / 1$ & $\begin{array}{l}\text { Exposure of Lemna minor to } \mathrm{TiO}_{2} \text { NPs increased the activities of various enzymes (POD, SOD, and CAT) } \\
\text { below concentration of } 200 \mathrm{mg} / \mathrm{l} \text { because of eliminating accumulated reactive oxygen species in plant cells. }\end{array}$ & Song, et al. [52] \\
\hline $\mathrm{Al}_{2} \mathrm{O}_{3}$ & $10-1000 \mathrm{mg} / \mathrm{l}$ & $\begin{array}{l}\text { The activity of SOD and CAT were increased with the treatments of } \mathrm{Al}_{2} \mathrm{O}_{3} \text { NPs at a concentration of } 200 \text { and } \\
500 \mathrm{mg} / \mathrm{l} \text {. }\end{array}$ & Riahi-Madvar, et al. \\
\hline $\mathrm{ZnO}$ & $10 \mathrm{mg} / 1$ & $\begin{array}{l}\text { Treatment of cluster bean with foliar sprays of } \mathrm{ZnO} \text { NPs caused a significant increase in chlorophyll content } \\
(276.2 \%) \text {, total soluble leaf protein }(27.1 \%) \text {, acid phosphatase }(73.5 \%) \text {, alkaline phosphatase }(48.7 \%) \text {, and } \\
\text { phytase }(72.4 \%) \text { over control. }\end{array}$ & Raliya and Tarafdar [54] \\
\hline $\mathrm{Fe}_{2} \mathrm{O}_{3}$ & $20 \mathrm{mg} / 1$ & $\begin{array}{l}\text { Increase in root activity, activity of catalase, peroxidase, superoxide dismutase, chlorophyll, malondialdehyde } \\
\text { contents, ferric reductase activity, the root apoplastic iron content were recorded by the translocation of the } \\
\text { significant amount of } \mathrm{Fe}_{2} \mathrm{O}_{3} \mathrm{NPs} \text { suspended in a liquid medium to various tissues of plants. }\end{array}$ & $\mathrm{Li}$, et al. [55] \\
\hline $\begin{array}{l}\text { SNP } \\
\mathrm{ZnO}\end{array}$ & $500-4,000 \mathrm{ppm}$ & $\begin{array}{l}\text { Application of various concentrations of both sulfur and zinc oxide nanoparticles in significantly increase the total } \\
\text { lipids, proteins, amino acids, thiol and chlorophyll contents compared to untreated control but no significance } \\
\text { difference has been observed among the treatments with various concentrations for both nanoparticles. }\end{array}$ & Patra, et al. [56] \\
\hline $\mathrm{TiO}_{2}$ & $200 \mathrm{mg} / 1$ & Application of $\mathrm{TiO}_{2}$ NPs had a noticeable effect on chlorophyll a and b and carotenoid contents on Mentha. & Samadi, et al. [57] \\
\hline
\end{tabular}


Table 3. Effect of nanoparticles on plant species and their metabolism

\begin{tabular}{|c|c|c|c|c|}
\hline Nanoparticles & Size range & Plant & Biological effects & Reference \\
\hline \multirow{4}{*}{$\mathrm{Ag}$} & $1-10 \mathrm{mg} \mathrm{L}^{-1}$ & Triticum aestivum $\mathrm{L}$. & Adversely affect seedling growth and & Vannini, et al. [49] \\
\hline & $1000-3000 \mathrm{mM}$ & Pisum sativum L. & chlorophyll fluorescence & Tripathi, et al. [50] \\
\hline & & Allium cepa & Caused oxidative stress and exhibited toxicity & Cvjetko, et al. [51] \\
\hline & $5-25 \mathrm{~nm} ; 0-40 \mathrm{mg} \mathrm{L}^{-1}$ & Phaseolus radiatus, & Higher accumulation in roots and shoots. & Lee, et al. [60] \\
\hline $\mathrm{Au}$ & $25-100 \mathrm{mg} \mathrm{L}^{-}$ & Arabidopsis thaliana, & Root length reduced by $75 \%$. Accumulation & Taylor, et al. [61] \\
\hline $\mathrm{CeO}_{2} \mathrm{ZnO}$ & $0.05-0.5 \mathrm{~g} \mathrm{~kg}^{-1}$ soil & Glycine max & Increased ROS, lipid peroxidation, visible & Priester, et al. [62] \\
\hline \multirow{2}{*}{$\mathrm{CuO}$} & $0-1000 \mathrm{mg} \mathrm{L}^{-1}$ & Conventional and & Inhibited the growth, development, nutrient & Van, et al. [63] \\
\hline & $200-500 \mathrm{mg} \mathrm{L}^{-1}$ & Ipt-cotton & Height and root length decreased, increased & Van, et al. [64] \\
\hline
\end{tabular}

\section{Role of nanotechnology in photosynthesis}

Photosynthesis is the procedure utilized by plants, green algae, and certain other microbes to prepare food. Photosynthesis is a key maker for plants on earth that changes light vitality to concoction vitality. Plants convert just $2-4 \%$ of the accessible vitality in radiation into new plant development [65]. Lin, et al. 2014, grew new tobacco plants by substituting the Rubisco quality for carbon-settling in the tobacco plant, with two qualities of cyanobacterium Synechococcus lengthens; these newly designed plants have more photosynthetic productivity than local plants.

It was reported that SWCNTs in the detached chloroplast enlarged multiple times higher photosynthetic activity than that of controls, and improved most extreme electron transport rates, and SWCNTs empowered the plants to detect nitric oxide, a singling substance [66]. Metal nanoparticles can prompt the productivity of synthetic vitality creation in photosynthetic frameworks [67]. The chlorophyll in photosynthetic response focus binds to the AuNPs and Ag nanocrystals, in this way framing a novel half framework that may create multiple times increasingly energized electrons due to plasmon surface response and quick electron-separation. The improvement components may help in the plan of light-harvesting frameworks.

\section{Effect of nanoparticles grain size distribution}

It was found that a reasonable connection between the grain estimate distribution of the field soil (for example the sand and earth content) and the toxic effect of AgNMs towards smelling salts oxidizing microscopic organisms. Past examinations have demonstrated that the maintenance of nanomaterials for the most part increments and the bioavailability decreases in soils with a better grain estimate distribution [68]. It is discovered that the danger of AgNMs accumulation in soils with a higher sand substance or lower mud content. The connection between AgNM toxicity and sand content was not straight but there was a decent connection between the sand content and higher danger. There was a superior connection between AgNM harmfulness and mud content, with just little deviations. The maintenance of AgNMs in common soil has recently been appeared to increment in accordance with the granulometric mud content [69] which may advance the heteroaggregation of AgNM and mud standard ticles, expanding the total size and making them less accessible to microorganisms, in this way bringing about a lower lethality. The arrangement of buildings with earth particles may likewise hinder the arrival of particles. It demonstrates that the soil grain measure dissemination is by all accounts the most critical soil property affecting the lethality of AgNMs.

\section{Effect of nanoparticles on $\mathrm{pH}$ of soil}

Soil $\mathrm{pH}$ is a significant factor that directly relates to soil fertility and health. It is an indication of acidic or alkalinity of the soil. Soil $\mathrm{pH}$ affects the availability of the nutrients for plants. It is proved that the nature of acidity or basicity of soil depends upon the composition of the soil. In general optimum $\mathrm{pH}$ range for plants is 5-7. It is observed that the $\mathrm{pH}$ of the soil may be influenced by the accumulation of the different type of nanoparticles like $\mathrm{Zn}, \mathrm{Ag}, \mathrm{Au}$, $\mathrm{Cu}$ etc. It was found that the $\mathrm{pH}$ of the soil also influences the toxicity of nanoparticles on the microorganisms and nematodes. The effect of organic matter and $\mathrm{pH}$ of the soil on the toxicity of $\mathrm{ZnO}$ nanoparticles on Folsomia candida [70]. It was found greater toxicity the effect of $\mathrm{Zn}$ nanoparticles then dissolved $\mathrm{Zn}$ on the bacterial community [71]. Very recently found that copper oxide nanoparticles may able to change the $\mathrm{pH}$ of paddy soil. Copper oxide nanoparticles cause an increase in the $\mathrm{pH}$ of soil which ultimately affects soil property. Uptake of Silver nanoparticles accumulated in soil by insects may also be influenced by the $\mathrm{pH}$ of the soil [72].

Soil $\mathrm{pH}$ seems to be the principal factor that governs concentrations of soluble metals. Zn solubility correlates negatively with $\mathrm{pH}$ [73]. Moreover, clay content in calcareous soil was higher than in acidic soil, which increase $\mathrm{Zn}$ retention in soil and hence, decreases $\mathrm{Zn}$ availability to microorganisms, as clays are believed to adsorb zinc ions across both ion exchange and specific adsorption. Zinc availability has also been connected to soil organic matter content. In this study, the soil organic matter content effect of content on $\mathrm{Zn}$ availability to microorganisms should be considered insignificant because values were very low and similar in both soils. The impacts of nanomaterials are firmly subject to the change forms they experience in nature. AgNM are oxidized in nature, and the release of silver particles might be in charge of the lethal effect [74]. Both the oxidation of AgNMs and the release of particles are reliant on the $\mathrm{pH}$ of the soil.

This concurs with previous findings about demonstrating that the toxicity of AgNMs towards earthworms is related with the particle content in the soil pore water [75]. The impact of $\mathrm{ZnO}$ nanomaterials is additionally caused for the most part by the released of particles, which proposes the outcomes ought to be similar with those watched for AgNMs. In like manner, the impact of $\mathrm{ZnO}$ nanomaterials on the proliferation of Folsomia candida demonstrated that the poisonous quality of metallic nanomaterials was reliant on soil $\mathrm{pH}$, and again that the danger expanded in progressively acidic soils. The impact of $\mathrm{Zn}$ danger on the multiplication of Eisenia fetida is affected by $\mathrm{pH}$ for all types of $\mathrm{Zn}$, reflecting the impact of $\mathrm{pH}$ on $\mathrm{Zn}$ disintegration [76].

\section{Effect of nanoparticles on soil organic carbon}

We additionally researched the effect of the natural carbon content on AgNM toxicity since this parameter may impact the impact of nanomaterials [77]. The natural carbon content differed between $0.93 \%$ and $3.85 \%$, however there was no connection between the natural carbon substance of the five soils we tried and the lethality of either AgNM or silver nitrate. 
There are signs in the writing that natural issue can change the impacts of nanomaterials, particularly those which discharge particles. For instance, the poisonous quality of AgNMs towards the freshwater zooplankton Ceriodaphnia dubia and Daphnia magna declined altogether as the broke down natural carbon content expanded [78]. AgNMs are less versatile in soils with a high substance of natural issue [79] in light of the fact that natural materials, for example, sewage slop connect with AgNMs, with sorption rates more prominent than $90 \%$ for uncoated particles [80] and lower rates for functionalized particles. Concentrates with biofilm networks and unadulterated societies have additionally appeared natural issue, for example, exopolysaccharides and humic acids can secure microorganisms and diminish the poisonous quality of AgNMs [81]. For instance, the nearness of Suwannee River humic acids made it difficult to decide an impact on the development of Pseudomonas fluorescens. In any case, these discoveries are for the most part from investigations in which the impact of natural carbon was tried on amphibian life forms though comparable information for soil life forms are increasingly constrained. It is already demonstrated that AgNMs and the particles discharged by them communicate with natural issue added to soil, diminishing the long haul harmful consequences for the aggregate of microbial exercises bringing about nitrate gathering [82]. The proposed mechanisms for the restraint of AgNM disintegration incorporate surface adsorption onto common natural issue (which thus forestalls AgNM oxidation and the arrival of silver particles) and the decreasing action of humic/fulvic acids which changes over oxidation items once more into silver metal [83].

\section{Effect of nanoparticles on microbial diversity}

As indicated by the examination directed by [84] $\mathrm{TiO}_{2}$ and $\mathrm{CuO}$ nanoparticles diminish the microbial biomass of the form soil and action of the chemical, influenced on their structures in overflowed paddy soil. Comparable outcomes were acquired biometal who contemplated the impact of $\mathrm{ZnO}, \mathrm{TiO}_{2}, \mathrm{CeO}_{2}$, andFe $\mathrm{O}_{4}$ nanoparticles on enzymatic activities of soil (invertase, urease, catalase, and phosphatase) and bacterial networks of the saline-soluble base and black soils. The outcomes demonstrated an effect on soil chemical exercises and changes in soil bacterial network and danger on natural nitrogen obsession. Results gotten have demonstrated that a high convergence of $\mathrm{Fe}_{3} \mathrm{O}_{4}$
NPs altogether diminished the substance of microscopic organisms in the soil. Zinc oxide and $\mathrm{CeO}_{2} \mathrm{NPs}$ influenced the plate checks of Azotobacter, P-solubilizing, and-solubilizing microscopic organisms and restrain enzymatic exercises [85]. Titanium dioxide NPs diminished the plenitude of utilitarian soil microscopic organisms and enzymatic activities and hindering impact on microbial action, occurrence, and diversity [86,87]. The information provided by [88] Maliszewska (2016) reported that the biogenic Au NPs up to the grouping of 33 $\mathrm{mg} \mathrm{kg}^{-1}$ don't influence the soil properties and their processes and can be delegated not destructive. Be that as it may, antibacterial exercises (development of a zone of inhibition) were seen on clinical disconnects (Bacillus subtilis, Escherichia coli, Klebsiellapneumonia, Pseudomonas aeruginosa, Salmonella typhi, and Staphylococcus aureus) treated with $\mathrm{ZnO}$ NPs incorporated by organic and concoction techniques [89].

Copper ions, released from the $\mathrm{Cu}$ NPs, were considered as a major cause of lethality to both the pathogenic and the beneficial bacteria [90]. It was investigated the effect of $\mathrm{CuO}$ and AgNPs on leaf microbial decomposition showing that exposure to these NPs led to a decrease in leaf decomposition rate (Table 4) [91-95].

The researchers observed that $\mathrm{TiO}_{2}$, at high concentrations, can disturb the symbiosis relationship between plant and bacteria and have a negative effect on the growth of clover. In natural soil, the mobility of the nanoparticles was weak and no increase in the uptake of titanium dioxide by the plants was found.

The mobility of MWCNT in soils was also weak; the experiments showed a concentration-independent uptake of MWCNT by the plants and a reduction in the number of red clover blossoms in the case of high concentrations. Both $\mathrm{TiO}_{2}$ and MWCNT in very high concentrations resulted in a change in the composition of the microbial communities that interact with the plants (Table 5) [96-99].

\section{Conclusion}

Nanobiotechnology accelerated almost every sector of agriculture sciences and crop research. It is well understood that the use of nanomaterial for the scientific and agriculture field enables a lot of advantages over conventional methods. Biofertilizers based on nanotechnology is quite useful for plant growth and developments.

Table 4. Effect of nanoparticles on soil microbial community and enzymes

\begin{tabular}{|c|c|c|}
\hline Nanomaterials & Major effect & References \\
\hline $\mathrm{Au}$ & Hinderance in enzymatic activities of soil & Asadishad, et al. \\
\hline $\mathrm{TiO}_{2}$ & The loss in diversity of the bacterial community & Ge, et al. [92] \\
\hline $\mathrm{Cu}$ & Decreases $\mathrm{C}, \mathrm{N}$ Biomass & Kumar, et al. [93] \\
\hline $\mathrm{Ag}$ & Loss of microbial community, hindrance in enzymatic activities & $\begin{array}{l}\text { Peyrote, et al. }[73] \\
\text { Colman, et al. }[74]\end{array}$ \\
\hline Mixture of $\mathrm{Cu}$ and $\mathrm{Fe}$ & Loss of microbial community & Ben-Mosey, et al. [41] \\
\hline Mixture of $\mathrm{Co}, \mathrm{Fe}, \mathrm{Ni}$ and $\mathrm{Ag}$ & Not much effect on the soil community & Shah, et al. [10] \\
\hline $\mathrm{Ag}$ & $\beta$-Glucosidase, acid phosphatase, dehydrogenase, Urease & Hnsch and Emmerling [94] \\
\hline $\mathrm{C}_{60}$ & $\begin{array}{l}\text { eucine-aminopeptidase, } \beta \text {-cellobiohydrolase, acid phosphatase, } \beta \text {-Glucosidase, } \\
\text { chitinase, xylosidase }\end{array}$ & Tong, et al. [95] \\
\hline
\end{tabular}

Table 5. Effect of nanoparticles on soil nematodes community

\begin{tabular}{|c|c|c|}
\hline Test Nanoparticles & Test species & Author/Year \\
\hline MWNT, $\mathrm{SWNT}$ & Eisenia foetida & Petersen, et al. $[96]$ \\
\hline $\mathrm{TiO}_{2}, \mathrm{ZnO}$ & Eisenia foetida & Hu, et al. $[97]$ \\
\hline $\mathrm{Al}_{2} \mathrm{O}_{3}$ & Eisenia foetida & Coleman, et al. $[98]$ \\
\hline $\mathrm{Pt}$ & Kim, et al. $[99]$ & Roh, et al. $[81]$ \\
\hline $\mathrm{Ag}$ & Caenorhabditis elegans & Ma, et al. \\
\hline $\mathrm{ZnO}$ & Caenorhabditis elegans & Roh, et al. . $[81]$ \\
\hline $\mathrm{CeO}_{2}, \mathrm{TiO}_{2}$ & Caenorhabditis elegans & \\
\hline
\end{tabular}


Biopesticides and no fungicides are more effective against disease and harmful insects. DNA delivery in crop research has become very easy with the help of nanobiotechnology. Uncontrolled and unregulated accumulation of nanomaterials in soil is a matter of concern. Since toxicity of nanomaterial is not unknown from late last decades. Investigations indication toxicity of nanomaterials is the emerging serious issue. Microbial community and soil health which directly or indirectly related to human health and wellbeing must be protected from the unnecessary deposition of nanomaterials.

\section{References}

1. Mishra S, Singh BR, Singh A, Keswani C, Naqvi AH, et al. (2014) Biofabricated silver nanoparticles act as a strong fungicide against Bipolaris sorokiniana causing spot blotch disease in wheat. PLoS One 9: e97881.

2. Mousavi SR, Rezaei M (2011) Nanotechnology in agriculture and food production. $J$ Appl Environ Biol Sci 1: 414-419.

3. Yang Y, Wang, Y, Westerhoff P, Hristovski K, Jin VL, et al (2014) Metal and nanoparticle occurrence in biosolid-amended soils. Science of the Total Environment 485: 441-449.

4. Weir A, Westerhoff P, Fabricius L, Hristovski K, Von Goetz N (2012) Titanium dioxide nanoparticles in food and personal care products. Environmental science technology 46 : 2242-2250.

5. McGillicuddy E, Murray I, Kavanagh S, Morrison L, Fogarty A, et al (2017) Silver nanoparticles in the environment: Sources, detection and ecotoxicology. Science of the Total Environment 575: 231-246.

6. Connolly M, Fernández M, Conde E, Torrent F, Navas JM, et al (2016) Tissue distribution of zinc and subtle oxidative stress effects after dietary administration of $\mathrm{ZnO}$ nanoparticles to rainbow trout. Science of The Total Environment 551: 334-343.

7. Keller AA, McFerran S, Lazareva A, Suh S (2013) Global life cycle releases of engineered nanomaterials. Journal of Nanoparticle Research 15: 1692.

8. Yadav T, Mungray AA, Mungray AK (2014) Fabricated nanoparticles: current status and potential phytotoxic threats. Reviews of Environmental Contamination and Toxicology volume 83-110.

9. Ben-Moshe T, Frenk S, Dror I, Minz D, Berkowitz B (2013) Effects of metal oxide nanoparticles on soil properties. Chemosphere 90: 640-646.

10. Kumar N, Shah V, Walker VK (2012) Influence of a nanoparticle mixture on an arctic soil community. Environmental toxicology and chemistry 31: 131-135.

11. Tiede K, Hanssen SF, Westerhoff P, Fern GJ, Hankin SM, et al. (2016) How important is drinking water exposure for the risks of engineered nanoparticles to consumers. Nanotoxicology 10: 1102-1110.

12. Tiede K, Boxall AB, Tear SP, Lewis J, David H, et al. (2008) Detection and characterization of engineered nanoparticles in food and the environment. Food additives and contaminants 25: 795-821.

13. Wang H, Zhao R, Li Y, Liu H, Li F, et al. (2016) Aspect ratios of gold nanoshell capsules mediated melanoma ablation by synergistic photothermal therapy and chemotherapy. Nanomedicine: Nanotechnology, Biology and Medicine 12: 439-448.

14. Sharma VK, Yngard RA, Lin Y (2009) Silver nanoparticles: green synthesis and their antimicrobial activities. Advances in colloid and interface science 145: 83-96.

15. Cho KH, Park JE, Osaka T, Park SG (2005) The study of antimicrobial activity and preservative effects of nanosilver ingredient. Electrochimica Acta 51: 956-960.

16. Morones JR, Elechiguerra JL, Camacho A, Holt K, Kouri JB, et al. (2005) The bactericidal effect of silver nanoparticles. Nanotechnology 16: 2346.

17. Tian J, Wong KK, Ho CM, Lok CN, Yu WY, et al. (2007) Topical delivery of silver nanoparticles promotes wound healing. ChemMedChem: Chemistry Enabling Drug Discovery 2: 129-136.

18. Oves M, Khan MS, Zaidi A, Ahmed AS, Ahmed F, et al. (2013) Antibacterial and cytotoxic efficacy of extracellular silver nanoparticles biofabricated from chromium reducing novel OS4 strain of Stenotrophomonas maltophilia. PloS one 8: e59140.

19. Mishra S, Singh BR, Singh A, Keswani C, Naqvi AH, et al. (2014) Biofabricated silver nanoparticles act as a strong fungicide against Bipolaris sorokiniana causing spot blotch disease in wheat. PLoS One 9: e97881.

20. Ali SM, Yousef NM, Nafady NA (2015) Application of biosynthesized silver nanoparticles for the control of land snail Eobania vermiculata and some plant pathogenic fungi. Journal of Nanomaterials p. 3.
21. Hojjat SS (2015) Impact of silver nanoparticles on germinated fenugreek seed. Int. $J$ Agric Crop Sci 8: 627-630.

22. Takkar PN, Walker CD (1993) The distribution and correction of zinc deficiency. In Zinc in soils and plants pp. 151-165.

23. Mortvedt JJ (1992) Crop response to level of water-soluble zinc in granular zinc fertilizers. Fertilizer research 33: 249-255.

24. Xie Y, He Y, Irwin PL, Jin T, Shi X (2011) Antibacterial activity and mechanism of action of zinc oxide nanoparticles against Campylobacter jejuni. Applied and environmental microbiology 77: 2325-2331.

25. Xia T, Kovochich M, Brant J, Hotze M, Sempf J, et al. (2006) Comparison of the abilities of ambient and manufactured nanoparticles to induce cellular toxicity according to an oxidative stress paradigm. Nano letters 6: 1794-1807.

26. Ryter SW, Kim HP, Hoetzel A, Park JW, Nakahira K, et al. (2007) Mechanisms of cell death in oxidative stress. Antioxidants redox signaling 9: 49-89.

27. Long TC, Saleh N, Tilton RD, Lowry GV, Veronesi B (2006) Titanium dioxide (P25) produces reactive oxygen species in immortalized brain microglia (BV2): implications for nanoparticle neurotoxicity. Environmental science technology 40: 4346-4352.

28. Panda SK, Chaudhury I, Khan M H (2003) Heavy metals induce lipid peroxidation and affect antioxidants in wheat leaves. Biologia Plantarum 46: 289-294.

29. Aarti PD, Tanaka R, Tanaka A (2006) Effects of oxidative stress on chlorophyll -biosynthesis in cucumber (Cucumis sativus) cotyledons. Physiologia Plantarum 128: 186-197.

30. Rajiv P, Rajeshwari S, Venckatesh R (2013) Bio-Fabrication of zinc oxide nanoparticles using leaf extract of Parthenium hysterophorus L. and its size-dependent antifungal activity against plant fungal pathogens. Spectrochimica Acta Part A: Molecular and Biomolecular Spectroscopy 112: 384-387.

31. Sang L, Zhao Y, Burda C (2014) TiO2 Nanoparticles as Functional Building Blocks. Chemical Reviews 114: 9283-9318.

32. Khodakovskaya MV, De Silva K, Biris AS, Dervishi E, Villagarcia H (2012) Carbon nanotubes induce growth enhancement of tobacco cells. ACS nano 6: 2128-2135.

33. Pelaez M, Nolan NT, Pillai SC, Seery MK, Falaras P, et al. (2012) A review on the visible light active titanium dioxide photocatalysts for environmental applications. Applied Catalysis B: Environmental 125: 331-349.

34. You T, Liu D, Chen J, Yang Z, Dou R, et al. (2018) Effects of metal oxide nanoparticles on soil enzyme activities and bacterial communities in two different soil types. Journal of Soils and Sediments 18: 211-221.

35. Santhoshkumar T, Rahuman AA, Jayaseelan C, Rajakumar G, Marimuthu S, et al (2014) Green synthesis of titanium dioxide nanoparticles using Psidium guajava extract and its antibacterial and antioxidant properties. Asian Pacific journal of tropical medicine 7: 968-976.

36. Rajkumar KS, Kanipandian N, Thirumurugan R (2016) Toxicity assessment on haemotology, biochemical and histopathological alterations of silver nanoparticlesexposed freshwater fish Labeo rohita. Applied Nanoscience 6: 19-29.

37. Chhipa H (2017) Nanofertilizers and nanopesticides for agriculture. Environmental chemistry letters 15: 15-22.

38. Cheng Z, Dong F, Xu J, Liu X, Wu X, et al. (2017) Simultaneous determination of organophosphorus pesticides in fruits and vegetables using atmospheric pressure gas chromatography quadrupole-time-of-flight mass spectrometry. Food chemistry 231 365-373.

39. Hasan S (2015) A review on nanoparticles: their synthesis and types. Research Journal of Recent Sciences 2277: 2502.

40. Chai H, Yao J, Sun J, Zhang C, Liu W, et al. (2015) The effect of metal oxide nanoparticles on functional bacteria and metabolic profiles in agricultural soil. Bulletin of environmental contamination and toxicology 94: 490-495.

41. Torsvik V, Øvreås L (2002) Microbial diversity and function in soil: from genes to ecosystems. Current opinion in microbiology 5: 240-245.

42. Jośko I, Oleszczuk P, Futa B (2014) The effect of inorganic nanoparticles ( $\mathrm{ZnO}$ $\mathrm{Cr} 2 \mathrm{O} 3, \mathrm{CuO}$ and $\mathrm{Ni}$ ) and their bulk counterparts on enzyme activities in different soils. Geoderma 232: 528-537.

43. Janvier C, Villeneuve F, Alabouvette C, Edel-Hermann V, Mateille T, et al. (2007) Soil health through soil disease suppression: which strategy from descriptors to indicators. Soil biology and Biochemistry 39: 1-23.

44. Suresh Y, Annapurna S, Bhikshamaiah G, Singh A K (2013) Characterization of green synthesized copper nanoparticles: A novel approach. In International Conference on Advanced Nanomaterials Emerging Engineering Technologies pp. 63-67. 
45. Bondarenko O, Juganson K, Ivask A, Kasemets K, Mortimer M, et al. (2013) Toxicity of $\mathrm{Ag}, \mathrm{CuO}$ and $\mathrm{ZnO}$ nanoparticles to selected environmentally relevant test organisms and mammalian cells in vitro: a critical review. Archives of toxicology 87: 1181-1200.

46. Simonin M, Richaume A (2015) Impact of engineered nanoparticles on the activity, abundance, and diversity of soil microbial communities: a review. Environmental Science and Pollution Research 22: 13710-13723.

47. Calvarro LM, de Santiago-Martín A, Gómez J Q, González-Huecas C, Quintana JR, et al. (2014) Biological activity in metal-contaminated calcareous agricultural soils: the role of the organic matter composition and the particle size distribution. Environmental Science and Pollution Research 21: 6176-6187.

48. Servin AD, White JC (2016) Nanotechnology in agriculture: next steps for understanding engineered nanoparticle exposure and risk. NanoImpact 1: 9-12.

49. Vannini C, Domingo G, Onelli E, De Mattia F, Bruni I, et al. (2014) Phytotoxic and genotoxic effects of silver nanoparticles exposure on germinating wheat seedlings. Journal of plant physiology 171: 1142-1148

50. Tripathi DK, Singh S, Singh S, Srivastava PK, Singh VP, et al. (2017) Nitric oxide alleviates silver nanoparticles (AgNps)-induced phytotoxicity in Pisum sativum seedlings. Plant physiology and biochemistry 110: 167-177.

51. Cvjetko P, Milošić A, Domijan AM, Vrček IV, Tolić S, et al. (2017) Toxicity of silver ions and differently coated silver nanoparticles in Allium cepa roots. Ecotoxicology and environmental safety 137 : 18-28.

52. Song MF, Li YS, Kasai H, Kawai K (2011) Metal nanoparticle-induced micronuclei and oxidative DNA damage in mice. Journal of clinical biochemistry and nutrition pp. 1202080139-1202080139.

53. RIAHI MA, Rezaee F, Jalali V (2012) Effects of alumina nanoparticles on morphological properties and antioxidant system of Triticum aestivum.

54. Raliya R, Tarafdar JC (2013) ZnO nanoparticle biosynthesis and its effect on phosphorous-mobilizing enzyme secretion and gum contents in Clusterbean (Cyamopsis tetragonoloba L.). Agricultural Research 2: 48-57.

55. Li Q, Chen X, Zhuang J, Chen X (2016) Decontaminating soil organic pollutants with manufactured nanoparticles. Environmental Science and Pollution Research 23: 11533 11548 .

56. Patra P, Choudhury SR, Mandal S, Basu A, Goswami A, et al. (2013) Effect Sulfur and $\mathrm{ZnO}$ Nanoparticles on Stress Physiology and Plant (Vignaradiata) Nutrition. Advanced Nanomaterials and Nanotechnology 2013: 301-309.

57. Samadi N, Yahyaabadi S, Rezayatmand Z (2014) Effect of TiO2 and TiO2 nanoparticle on germination, root and shoot Length and photosynthetic pigments of Mentha piperita. International Journal of Plant Soil Science 3: 408-418.

58. Khodakovskaya MV, De Silva K, Biris AS, Dervishi E, Villagarcia H (2012) Carbon nanotubes induce growth enhancement of tobacco cells. ACS nano 6: 2128-2135.

59. Ma X, Geiser-Lee J, Deng Y, Kolmakov A (2010) Interactions between engineered nanoparticles (ENPs) and plants: phytotoxicity, uptake and accumulation. Science of the total environment 408: 3053-3061.

60. Lee WM, Kwak JI, An YJ (2012) Effect of silver nanoparticles in crop plants Phaseolus radiatus and Sorghum bicolor: media effect on phytotoxicity. Chemosphere 86: 491499.

61. Taylor AF, Rylott EL, Anderson CW, Bruce NC (2014) Investigating the toxicity, uptake, nanoparticle formation and genetic response of plants to gold. PLOS one 9: e93793.

62. Priester JH, Moritz SC, Espinosa K, Ge, Y, Wang Y, Nisbet RM, Holden PA (2017) Damage assessment for soybean cultivated in soil with either $\mathrm{CeO} 2$ or $\mathrm{ZnO}$ manufactured nanomaterials. Science of the Total Environment 579: 1756-1768.

63. Le Van N, Ma C, Shang J, Rui Y, Liu S, et al. (2016) Effects of CuO nanoparticles on insecticidal activity and phytotoxicity in conventional and transgenic cotton. Chemosphere 144: 661-670.

64. Le Van N, Rui Y, Cao W, Shang J, Liu S, et al. (2016b) Toxicity and bio-effects of $\mathrm{CuO}$ nanoparticles on transgenic Ipt-cotton. Journal of Plant Interactions 11: 108-116.

65. Kirschbaum MU (2011) Does enhanced photosynthesis enhance growth? Lessons learned from CO2 enrichment studies. Plant physiology 155: 117-124.

66. Giraldo JP, Landry MP, Faltermeier SM, McNicholas TP, Iverson NM, Boghossian A A, Strano MS (2014) Plant nanobionics approach to augment photosynthesis and biochemical sensing. Nature materials 13: 400 .
67. .Govorov AO, Carmeli I (2007) Hybrid structures composed of photosynthetic system and metal nanoparticles: plasmon enhancement effect. Nano letters 7: 620-625.

68. . Shoults-Wilson WA, Reinsch BC, Tsyusko OV, Bertsch PM, Lowry GV, Unrine J M (2011) Effect of silver nanoparticle surface coating on bioaccumulation and reproductive toxicity in earthworms (Eisenia fetida). Nanotoxicology 5: 432-444.

69. Sagee O, Dror I, Berkowitz B (2012) Transport of silver nanoparticles (AgNPs) in soil. Chemosphere 88: 670-675.

70. Waalewijn-Kool PL, Ortiz MD, Van Straalen NM, van Gestel CA (2013) Sorption, dissolution and $\mathrm{pH}$ determine the long-term equilibration and toxicity of coated and uncoated $\mathrm{ZnO}$ nanoparticles in soil. Environmental pollution 178: 59-64.

71. Read DS, Matzke M, Gweon HS, Newbold LK, Heggelund L, et al. (2016) Soil pH effects on the interactions between dissolved zinc, non-nano-and nano- $\mathrm{ZnO}$ with soil bacterial communities. Environmental Science and Pollution Research 23: 4120-4128.

72. Pappa AM, Parlak O, Scheiblin G, Mailley P, Salleo A, et al. (2018) Organic electronics for point-of-care metabolite monitoring. Trends in biotechnology 36: 45-59.

73. Sauvé S, Hendershot W, Allen HE (2000) Solid-solution partitioning of metals in contaminated soils: dependence on $\mathrm{pH}$, total metal burden, and organic matter. Environmental science technology 34: 1125-1131.

74. Lowry GV, Espinasse BP, Badireddy AR, Richardson CJ, Reinsch BC, Bryant LD, Colman BP (2012) Long-term transformation and fate of manufactured Ag nanoparticles in a simulated large scale freshwater emergent wetland. Environmental science technology 46: 7027-7036.

75. Schlich K, Klawonn T, Terytze K, Hund-Rinke K (2013) Effects of silver nanoparticles and silver nitrate in the earthworm reproduction test. Environmental toxicology and chemistry 32: 181-188

76. Heggelund LR, Diez-Ortiz M, Lofts S, Lahive E, Jurkschat K, Wojnarowicz J, Svendsen C (2014) Soil pH effects on the comparative toxicity of dissolved zinc, nonnano and nano $\mathrm{ZnO}$ to the earthworm Eisenia fetida. Nanotoxicology 8: 559-572.

77. Aiken GR, Hsu-Kim H, Ryan JN (2011) Influence of dissolved organic matter on the environmental fate of metals, nanoparticles, and colloids. Environ Sci Technol 8: 31963201.

78. Cupi D, Hartmann NB, Baun A (2015) The influence of natural organic matter and aging on suspension stability in guideline toxicity testing of silver, zinc oxide, and titanium dioxide nanoparticles with Daphnia magna. Environmental toxicology and chemistry 34: 497-506.

79. Coutris C, Joner EJ, Oughton DH (2012) Aging and soil organic matter content affect the fate of silver nanoparticles in soil. Science of the Total Environment 420: 327-333.

80. Kaiser JP, Diener L, Wick P (2013) Nanoparticles in paints: a new strategy to protect façades and surfaces. In Journal of Physics: Conference Series 429: p012036.

81. Roh JY, Park YK, Park K, Choi J (2010) Ecotoxicological investigation of $\mathrm{CeO} 2$ and $\mathrm{TiO} 2$ nanoparticles on the soil nematode Caenorhabditis elegans using gene expression, growth, fertility, and survival as endpoints. Environmental toxicology and pharmacology 29: 167-172.

82. Schlich K, Hund-Rinke K (2015) Influence of soil properties on the effect of silver nanomaterials on microbial activity in five soils. Environmental pollution 196: 321330.

83. Liu J, Hurt RH (2010) Ion release kinetics and particle persistence in aqueous nanosilver colloids. Environmental science technology 44: 2169-2175.

84. Xu C, Peng C, Sun L, Zhang S, Huang H, et al. (2015) Distinctive effects of TiO2 and $\mathrm{CuO}$ nanoparticles on soil microbes and their community structures in flooded paddy soil. Soil Biology and Biochemistry 86: 24-33.

85. Cao J, Feng Y, Lin X, Wang J (2016) Arbuscular mycorrhizal fungi alleviate the negative effects of iron oxide nanoparticles on bacterial community in rhizospheric soils. Frontiers in environmental science 4: 10.

86. . Buzea C, Pacheco II, Robbie K (2007) Nanomaterials and nanoparticles: sources and toxicity. Biointerphases 2: 17.

87. Solanki A, Kim JD, Lee KB (2008) Nanotechnology for regenerative medicine: nanomaterials for stem cell imaging. Nanomedicine 3: 567-578.

88. Chai H, Yao J, Sun J, Zhang C, Liu W, et al. (2015) The effect of metal oxide nanoparticles on functional bacteria and metabolic profiles in agricultural soil. Bulletin of environmental contamination and toxicology 94: 490-495.

89. Maliszewska I (2016) Effects of the biogenic gold nanoparticles on microbial community structure and activities. Annals of Microbiology 66: 785-794. 
90. Venkataraju JL, Sharath R, Chandraprabha MN, Neelufar E, Hazra A, et al. (2014) Synthesis, characterization and evaluation of antimicrobial activity of zinc oxide nanoparticles. Journal of Biochemical Technology 3: 151-154.

91. Lofts S, Criel P, Janssen CR, Lock K, McGrath SP, et al. (2013) Modelling the effects of copper on soil organisms and processes using the free ion approach: Towards a multispecies toxicity model. Environmental pollution 178: 244-253.

92. Pradhan A, Seena S, Pascoal C, Cássio F (2011) Can metal nanoparticles be a threat to microbial decomposers of plant litter in streams. Microbial ecology 62: 58-68.

93. Ge Y, Schimel JP, Holden PA (2012) Identification of soil bacteria susceptible to TiO2 and $\mathrm{ZnO}$ nanoparticles. Appl Environ Microbiol 78:6749-6758.

94. Hänsch M, Emmerling C (2010) Effects of silver nanoparticles on the microbiota and enzyme activity in soil. Journal of Plant Nutrition and Soil Science 173: 554-558.
95. Tong M, Ding J, Shen Y, Zhu P (2010) Influence of biofilm on the transport of fullerene (C60) nanoparticles in porous media. Water research 44: 1094-1103.

96. Petersen EJ, Huang Q, Weber Jr WJ (2008) Bioaccumulation of radio-labeled carbon nanotubes by Eisenia foetida. Environmental science technology 42: 3090-3095.

97. Hu CW, Li M, Cui YB, Li DS, Chen J, et al. (2010) Toxicological effects of TiO2 and $\mathrm{ZnO}$ nanoparticles in soil on earthworm Eisenia fetida. Soil Biology and Biochemistry 42: 586-591.

98. Coleman JG, Johnson DR, Stanley JK, Bednar AJ, Weiss Jr CA, et al. (2010) Assessing the fate and effects of nano aluminum oxide in the terrestrial earthworm, Eisenia fetida. Environmental toxicology and chemistry 29: 1575-1580.

99. Kim E, Sun L, Gabel CV, Fang-Yen C (2013) Long-term imaging of Caenorhabditis elegans using nanoparticle-mediated immobilization. PloS one 8: e53419.

Copyright: $(\mathbb{C} 2019$ Javed Z. This is an open-access article distributed under the terms of the Creative Commons Attribution License, which permits unrestricted use, distribution, and reproduction in any medium, provided the original author and source are credited. 